\title{
The Analysis Effect of Leverage, Asymmetric Information and Corporate Governance to Firm Value in Manufacture Companies Listed in Indonesia Stock Exchange
}

\author{
Lisa Tyas Octaviana, Sri Hasnawati, Ernie Hendrawaty \\ Faculty of Economics and Business, University of Lampung, \\ Corresponding author: \\ Jl. Prof. Dr. Sumantri Brojonegoro No.1, Bandar Lampung 35145, Indonesia \\ lisatyas90@gmail.com
}

\begin{abstract}
Company value or Firm value is a certain condition that has been achieved by the company as an illustration of public trust and shareholders towards the company after going through an activity process for several years, since the company was first established until now. This study aims to determine the effect that occurs between Leverage, Asymmetric Information and Corporate Governance on the Firm Value through Cash Holdings as a mediating variable. The data used in this study are published financial report from 33 manufacturing companies in the Consumer Goods Industry Sector listed on the Indonesia Stock Exchange from 2011 - 201\%. The conclusion of this study is that cash holdings are only able to mediate the influence of corporate governance with a proxy proportion of the board independence on firm value. Directly cash holding and corporate governance with a proxy proportion of the number of independent commissioners also influence the firm value while leverage, asymmetric information and corporate governance with a proxy percentage of the number of share ownership by managerial does not directly affect the firm value of the company. So as to increase the value of the company, companies should determine the proportion of the right amount of board independence so it can create a good corporate government that can increase value of the company.
\end{abstract}

Keywords:

Firm Value, Leverage, Asymmetric Information, Corporate Governance, Cash Holdings 


\section{INTRODUCTION}

Every company is expected to adapt with changes in globalization and be able to read the situation that occurs in order to manage its management functions properly, starting from the fields of production, marketing, human resources, and finance. Every company owner will always show potential investors that their company is the right investment alternative. Therefore, firm value (firm value) becomes very important because it reflects the performance of the company that can affect investors' perceptions of the company (Suharli, 2006).

The company carries out various activities to achieve the stated objectives. Basically the main purpose of the company is to maximize the company's wealth and value which means maximizing shareholder wealth (Drobetz and Grüninger, 2007). Several studies have examined the factors that influence the value of companies in Indonesia and several other countries. Based on previous research, various results were obtained regarding the effect of leverage, asymmetric information and corporate governance on firm value.

Based on the background of the phenomena described previously accompanied by the many inconsistencies found in previous studies, the authors are interested in conducting research with the title "The Analysis Effect of Leverage Effect, Asymmetric Information and Corporate Governance To Firm Value with Cash Holdings as Mediating Variables in Manufacturing Companies on the Indonesia Stock Exchange «.

\section{Literature review \\ Pecking Order Theory}

Pecking Order theory suggests a set of funding sources in making corporate funding decisions (Jinkar, 2013). Based on this theory, when it needs funds for investment needs, the company finances investment opportunities with internal funds first. If the need for investment cannot be obtained from internal funding, the company will use external funding from debt as a second source of funding, and equity as the last funding source. In the Pecking Order Theory, cash will be a buffer between retained earnings and investment needs.

The Pecking Order Theory states that companies prioritize corporate financial sources, first, where the company prefers internal financing over external financing. Even when investor protection is low, managers will have an incentive in collecting cash to gain discretionary power over the company's investment decisions and not refer to outside investors (Ferreira and Vilela, 2004). In the pecking order theory, company insiders are more aware of shareholders and the decline in asymmetric information can increase the level of stock distribution without losing market value (Zohreh Anabestani and Mohammad Reza Shourvarzi, 2014).

\section{Asymmetric Information Theory}

Asymmetric Information is a condition where a party has more information than the other party. Because of asymmetric information, company management knows more about the company than investors in the capital market. The existence of asymmetry information, according to (Myers, 1983) has the conclusion that companies prefer to use the sequence, namely the first retained earnings and depreciation funds.

Asymmetric information has an effective role in providing external financing. Thus, the quality of accounting information can reduce the negative effects of asymmetric information and negative selection costs, 
which allows companies to reduce the level of corporate cash holdings. Cash holdings decrease when companies increase the use of bank debt and in the presence of cash replacements. In Contrast, companies with higher cash flows hold higher levels of cash.

\section{Signalling Theory}

Signaling theory states that a good quality company will intentionally give a signal to the market in the form of information, thus the market is expected to be able to distinguish good and bad quality companies (Solikah, Astuti and Paramitha, 2017). In order for the signal to be effective, it must be captured by the market and perceived well, and not easily imitated by poor quality companies (Marciano and Husnan, 2012).

Based on Signaling Theory, company performance is a factor that motivates companies to make stock split decisions. This is because the market will respond positively to signals where signals about the good future performance. Signals given by companies whose poor past performance will not be trusted by the market.

\section{Capital Structure Theory}

Capital structure is the way companies form the right side of the balance sheet consisting of capital and debt. Capital structure consists of short-term funding, long-term funding, and equity. Short-term and long-term debt can be obtained from external companies. Long-term debt will be used by companies to finance capital investments. Mortgage debt and bonds are examples of long-term debt. Mortgage debt can also be called a "secured debt".

\section{Good Corporate Governance}

In general, the implementation of good corporate governance is believed to improve company performance or value
(Hamonangan Siallagan, 2006). The concept of good corporate governance itself was introduced in Indonesia since 1999. The momentum for the introduction of GCG began after the formation of the National Committee on Governance Policy (KNKG) by the government. In 2000, the KNKG then issued a General Guideline for Good Corporate Governance in Indonesia which was later revised in 2006. In the guideline, a regulation states that each company must make a statement regarding the appropriateness of GCG implementation with the guidelines issued by the KNKG in its annual report. . That is, every company must be able to apply this GCG principle.

The application of the GCG mechanism is intended to reduce the occurrence of agency problems at the lowest point. In agency theory which states that agency problems can arise because of differences in interests between the company owner (Principal) and management (Agent) (Jensen and Meckling, 2012). When companies implement GCG, dividend and debt policies in an effort to increase the value of the company will be stronger results (Jensen and Meckling, 2012). This can be seen when managers make decisions in terms of company policies, such as in terms of leverage, dividends, compensation and others. When taking the policy, the manager (agent) will try to meet the principal objectives of the company, namely the prosperity of shareholders and the value of the company. This means that opportunistic behavior of agents can be minimized by the application of GCG. With this concept, the application of GCG can help reduce opportunities for managers to behave deviant and enrich themselves. That way, it is expected that there will be an increase in share prices and the prosperity of shareholders, through increasing the value of the company. 


\section{Firm Value}

Firm value can be measured using stock prices using a ratio called the valuation ratio. The valuation ratio is a ratio associated with evaluating the performance of company shares that have been traded in the capital market (go public) (Sudana, 2011). Valuation ratios provide information on how much the community appreciates the company, so people are interested in buying shares at a price higher than the book value. Tobins $Q$ is a method used to measure firm value in this study.

Tobin's $Q$ is a performance measure by comparing two assessments of the same asset. Tobin's $Q$ is a statistical description that functions as a proxy for firm value based on the perspective of the investor. Tobin's $Q$ has been used specifically by manufacturing companies to explain a number of diverse corporate phenomena (Sudiyatni and Puspitasari, 2010). The calculation element of Tobin's $Q$ is the market value of common stock and financial liabilites. The $Q$ ratio is superior to the ratio of market value to book value because this ratio focuses on what the current value of the company is relative to the cost needed to replace it now.

\section{Cash Folding}

Cash holdings are the amount of cash held by the company to carry out various company activities (Ginglinger and Saddour, 2012). Cash holdings is a ratio that compares the amount of cash and cash equivalents owned by the company with the total assets of the company as a whole (García-Teruel, Martínez-Solano and Sánchez-Ballesta, 2009). It was also revealed that in a perfect capital market, cash holdings are irrelevant. This is because the company will easily obtain funds from the external market. But in imperfect capital markets, cash holdings are important because they are related to the availability of cash to finance various company activities.

\section{IMFTHODS \\ Sampling}

The sample selection method in this study uses a purposive sampling method, namely the selection of samples from the population with a specific purpose so that the selected sample can represent the entire population, where the sample must have certain criteria (Hartono, 2016). Based on predetermined criteria, the total population of 151 companies and a sample of 33 companies with a sevenyear research period, namely from 2011 to 2017 in companies listed on the Indonesia Stock Exchange.

\section{Data Collection}

The type of data used in this study is secondary data. The data is in the form of sample companies' financial ratios viewed from the 2011-2017 financial statements audited and then published. Data that used in this research was obtain and accessed through the website www.idx.co.id.

\section{IMeasurement}

The measurements used in this study use four stages of analysis, namely Descriptive Analysis, Classical Assumption Test Analysis, Analysis of Goodness Of Fit Model Test, and Linear Regression Analysis. In Linear Regression Analysis, testing is done twice, namely directly on the independent variable and through mediating variables using the sobel statistical test..

\section{RESULTS AND DISCUSSION}

\section{Goodness Fit Of Model Results}

Based on the $\mathrm{R}^{2}$ of each dependent variable, a predictive -relevance $\left(\mathrm{Q}^{2}\right)$ value can be calculated:

$$
\begin{aligned}
\mathrm{Q}^{2} & =1-\left(1-\mathrm{RI}^{2}\right)\left(1-\mathrm{RR}^{2}\right) \\
& =1-(1-0,497)(1-0,184)
\end{aligned}
$$


Table 1. Summary of the Results of Multiple Linear Regression Between Leverage, Asymmetric Information, Board Independence, Managerial Ownership and Cash Holdings To Firm Values

\begin{tabular}{lrrl}
\hline \multicolumn{1}{c}{ Variabel } & Coefficient & t-statistic & Prob \\
\hline Constant & 6,229 & 4,032 & 0,000 \\
DAR & $-0,146$ & $-1,216$ & 0,227 \\
BAS & $-0,111$ & $-1,172$ & 0,244 \\
BINDEP & $-0,367$ & $-3,764^{* *}$ & 0,000 \\
KEPM & $-0,065$ & $-0,709^{*}$ & 0,480 \\
CH & 0,259 & $2,025^{* *}$ & 0,046 \\
\hline F-statistic & & $4,462^{* *}$ & 0,001 \\
R Square & & 0,184 & \\
Adjusted R Square & & 0,143 & \\
Durbin-Watson & & 1,197 & \\
$\mathrm{~N}$ & & 105 & \\
\hline
\end{tabular}

Notes: Table 1 presents the equation of the results of multiple linear regression with cash ownership as the dependent variable, with a significance level of 5\%

Table 2. Summary Results of Direct Effect to Firm Value

\begin{tabular}{lccc}
\hline Variable & Hypothesis & Findings & Results \\
\hline $\mathrm{DAR} \rightarrow \mathrm{Q}$ & Significant & Not Significant & $\mathrm{H}_{5}$ Rejected \\
$\mathrm{BAS} \rightarrow \mathrm{Q}$ & Significant & Not Significant & $\mathrm{H}_{6}$ Rejected \\
$\mathrm{BINDEP} \rightarrow \mathrm{Q}$ & Significant & Negative Significant & $\mathrm{H}_{7}$ Accepted \\
$\mathrm{KEPM} \rightarrow \mathrm{Q}$ & Significant & Not Significant & $\mathrm{H}_{8}$ Rejected \\
$\mathrm{CH} \rightarrow \mathrm{Q}$ & Significant & Positive Significant & $\mathrm{H}_{9}$ Accepted \\
\hline
\end{tabular}

$$
\begin{aligned}
& =1-(0,503)(0,816) \\
& =1-(0,410) \\
Q^{2} & =0,589
\end{aligned}
$$

The $Q^{2}$ value obtained is 0.589 which means that the model is used to predict the feasibility of the dependent variable as a basis for testing the hypothesis. The total coefficient of determination of $58.9 \%$ is a good enough and accurate value to predict the value of the company, the remaining $41.1 \%$ is not included in this research model.

\section{Direct Fffect Test Result On Firm Value} (Tobin's Q)

Based on Table 1, the results of the linear regression test with the dependent variable firm value (Tobin's $Q$ ) with the independent variable leverage (DAR), Asymmetric Information (BAS), Corporate Governance
(BINDEP, KEPM) and Cash Holdings (CH), it can be concluded that the direct effect of firm value is leverage, asymmetric information, corporate governance and cash holdings are shown in Table 2.

\section{Indirect Fffects Test Result on Firm Value or Through Cash Holdings as A IMediation \\ Variable}

Based on Table 3, the calculation of the value of indirect effects and the results of the sobel test statistic with cash holdings as a mediating variable between the relationship of firm value (Tobin's $Q$ ) and leverage, asymmetric information, corporate governance, it can be concluded as in Table 4.

\section{DISCUSSION}

Based on the main objective of this research is to help companies in increasing the value 
Table 3. Indirect Effect Results through Cash Holdings as Mediation Variable

\begin{tabular}{cccc}
\hline $\begin{array}{c}\text { Independent } \\
\text { Variable }\end{array}$ & $\begin{array}{c}\text { Indirect Effect } \\
\text { Value }\end{array}$ & $\begin{array}{c}\text { Total Effect } \\
\text { Value }\end{array}$ & $\begin{array}{c}\text { p-value of sobel } \\
\text { test results }\end{array}$ \\
\hline DAR & -0.153 & -0.299 & 0.297 \\
BAS & 0.046 & -0.065 & 0.118 \\
BINDEP & 0.063 & -0.304 & 0.083 \\
KEPM & -0.003 & -0.068 & 0.874 \\
\hline
\end{tabular}

Table 4. Summary Results of Indirect Effect through Cash Holdings as Mediating Variable

\begin{tabular}{lccc}
\hline Variable & Hypothesis & Finding & Results \\
\hline $\mathrm{DAR} \rightarrow \mathrm{CH} \rightarrow \mathrm{Q}$ & Mediating & Not able to mediate & $\mathrm{H}_{10}$ Rejected \\
$\mathrm{BAS} \rightarrow \mathrm{CH} \rightarrow \mathrm{Q}$ & Mediating & Not able to mediate & $\mathrm{H}_{11}$ Rejected \\
$\mathrm{BINDEP} \rightarrow \mathrm{CH} \rightarrow \mathrm{Q}$ & Mediating & Mediating & $\mathrm{H}_{12}$ Accepted \\
$\mathrm{KEPM} \rightarrow \mathrm{CH} \rightarrow \mathrm{Q}$ & Mediating & Not able to mediate & $\mathrm{H}_{13}$ Rejected \\
\hline
\end{tabular}

of the company's shares so that it can attract investors in investing their capital. Therefore, this study checks the direct influence of changes in the value of the company and also through cash holdings as a mediating variable in order to compare whether the mediating variable changes in firm value can be higher or increase the value of the company.

By using multiple linear regression tests directly or through mediation variables, the summary results are obtained as shown in Table 5

Based on the test results directly or through mediating variables, variable that have an influence on the value of the company is the board independence variable as a proxy of corporate governance. If a company has more and more independent commissioners, the company will be judged to be getting better too, because the company will be considered to have financial supervision

Table 5. Summary Results

\begin{tabular}{llll}
\hline Variable & Hypothesis & Finding & Results \\
\hline $\mathrm{DAR} \rightarrow \mathrm{CH}$ & Significant & Negative Significant & $\mathrm{H}_{1}$ Accepted \\
$\mathrm{BAS} \rightarrow \mathrm{CH}$ & Significant & Positive Significant & $\mathrm{H}_{2}$ Accepted \\
$\mathrm{BINDEP} \rightarrow \mathrm{CH}$ & Significant & Positive Significant & $\mathrm{H}_{3}$ Accepted \\
$\mathrm{KEPM} \rightarrow \mathrm{CH}$ & Significant & Not Significant & $\mathrm{H}_{4}$ Rejected \\
$\mathrm{DAR} \rightarrow \mathrm{Q}$ & Significant & Not Significant & $\mathrm{H}_{5}$ Rejected \\
$\mathrm{BAS} \rightarrow \mathrm{Q}$ & Significant & Not Significant & $\mathrm{H}_{6}$ Rejected \\
$\mathrm{BINDEP} \rightarrow \mathrm{Q}$ & Significant & Negative Significant & $\mathrm{H}_{7}$ Accepted \\
$\mathrm{KEPM} \rightarrow \mathrm{Q}$ & Significant & Not Significant & $\mathrm{H}_{8}$ Rejected \\
$\mathrm{CH} \rightarrow \mathrm{Q}$ & Significant & Positive Significant & $\mathrm{H}_{9}$ Accepted \\
$\mathrm{DAR} \rightarrow \mathrm{CH} \rightarrow \mathrm{Q}$ & Mediate & Not Mediate & $\mathrm{H}_{10}$ Rejected \\
$\mathrm{BAS} \rightarrow \mathrm{CH} \rightarrow \mathrm{Q}$ & Mediate & Not Mediate & $\mathrm{H}_{11}$ Rejected \\
$\mathrm{BINDEP} \rightarrow \mathrm{CH} \rightarrow \mathrm{Q}$ & Mediate & Mediate & $\mathrm{H}_{12}$ Accepted \\
$\mathrm{KEPM} \rightarrow \mathrm{CH} \rightarrow \mathrm{Q}$ & Mediate & Not Mediate & $\mathrm{H}_{13}$ Rejected \\
\hline
\end{tabular}


and good management. However, in reality out of 33 companies in the study there were still seven companies that did not have an independent board of commissioners. This caused many companies that did not have good corporate governance and alleged agency problems.

These companies have not followed the rules set by the Financial Services Authority where a company goes public must have at least 1 board of commissioners of a total of 2 commissioners, or $30 \%$ of the number of board of commissioners if the number of commissioners of the company is more than 2 people. This can explain that the addition of independent board members is only carried out to fulfill formal provisions, while the majority shareholders (founders) still play an important role so that the performance of independent commissioners does not increase.

As research conducted by Arifin (2012) found that corporate governance with indicators of the proportion of independent commissioners has a negative effect on firm value. The same results obtained in this study where board independence as a proxy of corporate governance has a negative influence on firm value. Beside that, independent commissioners as part of the role of corporate governance are considered able to oversee or monitor the amount of cash available in the company and can control agency problems caused by excess cash holdings. Where excess cash holdings has a strategic function so that it can play a role in determining the value of the company (Hendrawaty, 2015).

Based on the results stated previously that cash holdings are only able to mediate the relationship between corporate governance and board independence proxy on firm value, besides that corporate governance with board independence proxy also has a direct effect on the value of the company. So as to increase the value of the company, the company should determine the right proportion of board independence so that the company can create a good corporate governance that can increase the value of the company.

Subsequent research is recommended to examine variables with indicators other than indicators that have been used in research to obtain results that can more influence company value variables such as debt to equity ratio for leverage and other proxies from corporatae governance such as company size, non director presentation -executive as well as the proportion of institutional investors. In addition, in subsequent studies it is expected that the number of samples used should be greater with a longer observation period so that the results can be generalized and have a tendency in the long run.

\section{Conclusion}

The hypothesis which states that Leverage, Asymmetric Information and Corporate Governance with the Board of Independence proxy directly affects the supported Cash Holdings. Thus based on the four independent variables tested, only Leverage variables, Asymmetric Information and Corporate Governance with the Board Independence proxy are factors that can influence the amount of cash held by the company.

The hypothesis which states that Corporate Governance with the proxy of Board Independence and Cash Holdings directly influences the value of the supported company. Based on the five independent variables tested it was proven that only Corporate Governance variables with the 
Board Independence and Cash Holdings proxy were factors that could influence the size of the value of a company.

The hypothesis which states that Cash Holdings is able to mediate the relationship between Corporate Governance with the Board of Independence proxy for the value of the company is supported. Based on the results of testing on four independent variables and cash holdings as mediating variables, only the relationship of corporate governance variables with board independence proxy to firm value is mediated by variable cash holdings.

\section{REFERENCES}

Drobetz, W. and Grüninger, M.C., 200\%. Corporate cash holdings: Evidence from Switzerland. Financial Markets and Portfolio Management.

Ferreira, M.A. and Vilela, A.S., 2004. Why do firms hold cash? Evidence from EMU countries. European Financial Management.

García-Teruel, P.J., Martínez-Solano, P. and Sánchez-Ballesta, J.P., 2009. Accruals quality and corporate cash holdings. Accounting and Finance.

Ginglinger, E. and Saddour, K., 2012. Cash Holdings, Corporate Governance and Financial Constraints. Ssrn.

Hamonangan Siallagan, M.M., 2006. Mekanisme Corporate Governance, Kualitas Laba Dan Nilai Perusahaan. Simposium Nasional Akuntansi 9 Padang.

Hartono, J., 2016. Teori Portofolio dan Analisis Investasi. BPFE- Yogyakarta.

Hendrawaty, E., 2015. Peran Corporate Governance Dalam Mengendalikan Masalah Keagenan Yang Ditimbulkan Oleh Excess Cash Holdings. Universitas Gajah Mada.

Jensen, M. and Meckling, W., 2012. Theory of the firm: Managerial behavior, agency costs, and ownership structure. In: The Economic Nature of the Firm: A Reader, Third Edition.

Jinkar, T.R., 2013. Analisa faktor- faktor penentu kebijakan cash holdings perusahaan manufaktur di Indonesia.

Marciano, D. and Husnan, S., 2012. The Impact of Information Asymmetry, Moral Hazard and the Structure of Funding on Corporate U.S. Dollars Loan Pricing: The Empirical Study in Indonesia the Period 1990-1997. SSRN.

Myers, S.C., 1983. The Capital Structure Puzzle.

Solikah, M., Astuti, P. and Paramitha, A., 201\%. Pengaruh Profitabilitas, Likuiditas dan Leverage Dalam Memprediksi Financial Distress (Studi Empiris Pada Perusahaan Manufaktur yang Terdaftar di BEI Periode 2009-2013). JURNAL AKUNTANSI \& EKONOMI FE. UN PGRI Kediri Vol. 2 No. 1, Maret 201\%.

Sudana, I.M., 2011. Manajemen Keuangan Perusahaan Teori \& Praktik. Erlangga.

Sudiyatni, B. and Puspitasari, E., 2010. Tobin's Q Dan Altman Z-Score Sebagai Indikator Pengukuran Kinerja Perusahaan Tobin's Q and Altman Z-Score as Indicators of Performance Measurement Company. Kajian Akuntansi, 2(1), pp.9-21.

Suharli, M., 2006. Studi Empiris Mengenai Pengaruh Profitabilitas,Leverage, dan Harga Saham terhadap Jumlah Dividen Tunai (Studi pada perusahaan yang terdaftar di Bursa Efek Jakarta periode 2002-2003). Jurnal Universitas Katolik Indonesia Atma Jaya.

Zohreh Anabestani and Mohammad Reza Shourvarzi, 2014. Cash Holdings, Firm Value and Corporate Governance. Middle-East Journal of Scientific Research, 21(10), pp.1737-1745. 